gestions that students might be economically housed in blocks of houses resembling council houses should be carefully considered on their merits. Are university planning authorities familiar with the 'student villages' at Oslo and Upsala? Such an approach may be the only answer to what is admittedly a difficult problem.

The spirit and standards adopted by the Ministry of Education and local education authorities to meet successive crises in primary and secondary schools since the Second World War may point the way whereby the universities can deal with their expansion problems. For in considering their own needs they should never forget the needs of the country as a whole. When inviting industrial organizations to contribute vast sums of money to provide adequate facilities for much-needed scientists and technologists, university authorities would do well to remember that much of that money comes from many firms where facilities for training school recruits are inadequate by any respectable standards.

Sir James Mountford, too, has given a salutary warming to university empire-builders. We should be spared the spectacle of heads of postgraduate departments having to canvass for and accept students of less than degree standard to build up classes of adequate size. University expansion must go handin hand with expansion of educational facilities in all kinds of schools and in industry itself. Technologists are of little use without technicians who, in turn, need craftsmen to serve them. There are many who feol that, desperate as is our plight for technologists, in ten years time our greatest deficiency may be the lack of adequately trained technicians and craftsmen.

\section{THE PROFESSION OF SCIENCE}

The Organisation of Science in England

A Retrospect. By Dr. D. S. L. Cardwell. (Heinemanr Books on Sociology.) Pp. ix +204 . (London : William Heinemann, Ltd., 1957.) 18s. net.

$T$ was not for want of urging that Englishmen have been slow to appreciate the educational implication of the revolution initiated by applied science. As early as 1832 Baden Powell, Savilian professor of geometry at Oxford, condemned the practice of allowing graduates to leave the university ignorant of science. Lectures in chemistry and experimental philosophy were, in his time, losing their appeal, and the proportion of those taking honours in mathematics was also steadily falling. He ascribed it to the faulty education provided by the schools. Charles Babbage, Lucasian professor of mathematics at Cambridge, was even more outspoken and, two years before, in "Observations on the Decline of Science in England", lamented that "the pursuit of science does not constitute a distinct profession as it does in other countries".

To obtain professional status for scientists, Dr. Cardwell argues there had to be a series of changes in the educational system. "The professional scientist," he writes, "is, in the first instance, the product of the educational system; to a much less extent is he the product of industrial practice and economic organisation."
This book is written around the provocative thesis that industry did not demand professional scientists until the universities produced them. In other words, the first professional scientists produced were teachers, and the present voracious appetite which industry exhibits for professional scientists has grown with feeding. To support this thesis, Dr. Cardwell has combed the nineteenth-century journals, Nature included. He rightly gives full credit to Liebig and Helmholtz for helping to convert the English to a need to train scientists. They exported men and ideas in the eighteen-forties. The men included Caro, Fischer, Fries, Bopp, Griess, Geyger, Kolbe, Leibius, Holtzmann, Ulrich, Martius, Olshausen, Wilbrand, Sell and Witt : the first of these only left England in 1867 and the last in 1879. During this period they served English industry and science before England was producing men of similar calibre. For the fine crop of projects for industrial universities and even ministries of science which Dr. Cardwell has exhumed needed rooting in good schools, and sustentation by a capacity-catching (or capacityattracting) system. Neither was available.

So, to slake what the Edinburgh Review called "the sacred thirst for science", there arose the mechanics institutes : those 'steam intellect societies' that evoked the post-prandial jokes of the upper class. Baden Powell, watching their spread, remarked that unless the upper class followed suit, "that class will not long remain the higher". By the time of the Great Exhibition, plans were afoot to federate the mechanics institutes into a national network of colleges of technology. Soon after, the Government created the most formidable instrument for scientific education to date-the Science and Art Department. This Department did much to tap "the vast reservoir of unfriended talent" (as the Rev. James Booth called it) that lay stagnant in Victorian England. Aptly enough, access to this reservoir was obtained by Sappers: officers of the Royal Engineers were employed by the Science and Art Department as school inspectors and examination supervisors. The most distinguished of these, John Donnelly, rose from captain to major-general in the process of tapping this reservoir : he enjoyed throughout his professional life the friendship of 'T. H. Huxley, and earned at his death an obituary in Nature. The Army also nourished Col. Alexander Strange, Fellow of the Royal Society, who insisted that only the State could adequately support the advance of science. As Dr. Cardwell writes, "it is a testimony to his judgment that practically everything he called for has, today, been realised". It is the story of this realization which provides the core of Dr. Cardwell's book, and it should be read by all those whose professional ancestry he has sketched with such intimate detail.

W. H. G. Armytage

\section{VETERINARY OPHTHALMOLOGY}

Veterinary Ophthalmology

By R. H. Smythe. Pp. xii $+356+15$ plates. (London: Baillière, Tindall and Cox, Ltd., 1956.) 35s. net.

$T$ HIS book will be welcomed by veterinary surgeons, students and others interested in the mammalian and avian eye. The work presents, in the form of a concise and readable text-book, the existing knowledge of ophthalmology as it may be applied to the study and treatment of animals. The book 